\title{
Comparative biology and predatory potential of green lace wing on different aphid species
}

\author{
S.M. PATEL, G.G. RADADIA, H.V. PANDYA*, S.D. PATEL AND P.P. DAVE
}

Department of Entomology, ASPEE College of Horticulture and Forestry, Navsari Agricultural University, NAVSARI (GUJARAT) INDIA

\section{ARITCLE INFO}

Received : 25.11 .2014

Revised : 05.01 .2015

Accepted : 19.01.2015

KEY WORDS :

Green lace wing, Comparative biology, Predatory potential

*Corresponding author: Email: hvpandya@nau.in

\begin{abstract}
Investigation on comparative biology of green lace wing, Chrysoperla zastrowi arabica Henry et al. (Neuroptera : Chrysopidae) was carried out in the Bio-control Laboratory, Navsari Agricultural University, Navsari, Gujarat during 2007 to 2009. The results on comparative biology of C. zastrowi arabica on two aphid species viz., Aphis gossypii Glower and Myzus persicae (Sulzer) revealed that average duration of total developmental period was $18.70 \pm 0.64$ and $18.93 \pm 0.55$ days when reared on A. gossypii, and M. persicae, respectively. The egg laying capacity of $C$. zastrowi arabica was recorded $754.25 \pm 143.47$ and $601.75 \pm 89.43$ eggs when reared on A. gossypii and M. persicae, respectively. Study on predatory potential of $C$. zastrowi arabica revealed that single larva consumed an average of $627.60 \pm 42.39$ and $587.5 \pm 55.59$ numbers (nymphs and adults) of $A$. gossypii and $M$. persicae, respectively.
\end{abstract}

How to view point the article : Patel, S.M., Radadia, G.G., Pandya, H.V., Patel, S.D. and Dave, P.P. (2015). Comparative biology and predatory potential of green lace wing on different aphid species. Internat. J. Plant Protec., 8(1) : 13-20. 